\title{
미국, 중국, 일본의 대 아프리카 협력 동향 및 시사점
}

조 혜 승 (KOICA 동아프리카팀 과장)

목 차
I. 서언
II. 미국 오바마 대통령 아프리카 순방
III. 중국 시진핑 주석 아프리카 순방
IV. 일본 TICAD 개최 및 아베 이니셔티브
V. 시사점
VI. 결어

\section{I . 서언}

2013년은 미국과 중국 정상의 잇따른 아프리카 순방과 일본의 아프리카 개발을 위한 도쿄 국제 컨퍼런스(TICAD, Tokyo International Conference for African Development) 개최로 이들 3 국의 대 아프리카 지원방향을 엿볼 수 있는 시기였다. 미국 오바마 대통령은 탄자니아, 남아공, 세네갈 순방 시 파워 아프리카(Power Africa)와 무역 아프리카(Trade Africa)를 내세 워 전력분야 및 무역/투자를 위한 협력을 강조하였으며, 중국 시진핑 주석은 탄자니아와 남아 공, 콩고공화국을 방문하며 인프라 지원과 인적역량 강화를 강조하였다. 요코하마에서 개최된 TICAD에서는 2013 요코하마 선언과 행동계획이 채택되고, 일본의 대 아프리카 지원을 위한 패키지의 일환으로 아베 이니셔티브가 발표된바 있다. ${ }^{1)}$

1) $A B E$ Initiative, African Business Education Initiative for Youth 
천년개발목표(MDG, Millennium Development Goals)의 달성시한이 2년 남짓으로 다가온 시점에서 국제사회는 기존 8가지 목표를 달성하기 위해 노력하는 한편 Post-MDG를 준비하 고 있으며, 이러한 맥락에서 미, 중, 일 3 국이 향후 아프리카와의 협력을 위한 분야와 방법을 어떻게 제시하는지를 관찰하는 것은 의미있는 것으로 보인다.

아울러, 본 글에서는 3 국의 대 아프리카 지원동향이 우리나라의 아프리카 협력에 시사하는 바를 고찰하고, 향후 아프리카 협력 방향을 제언하도록 하겠다.

\section{II. 미국 오바마 대통령 아프리카 순방}

미국 오바마 대통령은 6 월 27 일부터 7 월 2 일간 세네갈과 남아공, 탄자니아를 순방하며 정부 와 기업, 시민사회단체의 주요 인물을 만나 인프라 구축, 투자 및 무역의 확대, 식량안보와 보 건의료, 인적역량 강화를 위한 미국의 지원을 강조했다.

\section{1. 파워 아프리카(Power Africa)}

금번 순방기간 중에 발표한 파워 아프리카(Power Africa)는 사하라 이남 아프리카의 전력 접근성 배가(倍加)를 위한 이니셔티브로, 석유와 가스 신규 발굴 및 지열, 수력, 풍력, 태양에 너지 등 대체에너지 개발이 주요 목적이다.

사하라 이남 아프리카 전체 인구의 $2 / 3$, 농촌지역의 $85 \%$ 는 전력에 대한 접근권이 없으며, 이들 전체 인구에 대한 전력 접근성 향상을 위해서는 2030 년까지 3 천억불 이상의 예산이 필요 한 것으로 보인다. ${ }^{2)}$ 따라서, 파워 아프리카 목표 달성을 위해서는 정부 차원의 지원뿐만 아니 라 민간의 참여가 필수적이며, 미국은 향후 5 년간 총 70 억불 상당의 정부차원 재정지원과 함 께 전력 8천 메가와트 개발을 위한 민간부문의 투자를 약속했다.

2) IEA, International Energy Agency 
- 정부차원 지원 약속사항 : 향후 5 년간 총 70 억불 이상 재정지원 약속

\begin{tabular}{|c|c|c|}
\hline 기관 & 약속금액 & 주요내용 \\
\hline USAID & 285백만불 & $\begin{array}{l}\text { 민간투자 활성화를 위한 기술협력, 위험완화, 무상지원(수 } \\
\text { 원국 법률/제도 정비, 정책 자문) }\end{array}$ \\
\hline OPIC & 15억불 & 에너지 개발사업을 위한 재정 및 보증 지원 \\
\hline US Ex-Im & 50 억불 & 사하라 이남 아프리카의 대미 수출 지원 \\
\hline $\mathrm{MCC} 3)$ & 10억불 & $\begin{array}{l}\text { 에너지 인프라 구축, 관련 정부정책, 제도정비 지원 및 수 } \\
\text { 원국 관련기관 역량강화 지원 }\end{array}$ \\
\hline OPIC, USTAD & 20백만불 & 재생에너지 개발을 위한 타당성조사, 기술협력 \\
\hline USADF & 2백만불 & $\begin{array}{l}\text { 소외지역 오프그리드(off-grid) 에너지 공급을 위한 아프리 } \\
\text { 카(African owned, operated) 에너지 관련 중소기업 지원 }\end{array}$ \\
\hline OPIC, USAID & - & $\begin{array}{l}\text { “아프리카 에너지 및 인프라 투자 컨퍼런스” 공동 개최, 미 } \\
\text { 국 기업인 및 투자자, 정부 관계자 참여 }\end{array}$ \\
\hline
\end{tabular}

- 민간부문 투자 약속사항 : 전력 8천 메가와트 개발, 최초 90 억불 투자 약속

\begin{tabular}{c|c|l}
\hline $\begin{array}{c}\text { 기업 } \\
\begin{array}{c}\text { General } \\
\text { Electric }\end{array}\end{array}$ & 약속금액 & \multicolumn{1}{|c}{ 주요내용 } \\
\hline $\begin{array}{c}\text { Heirs } \\
\text { Holdings }\end{array}$ & 25억불 & $\begin{array}{l}\text { 탄자니아 및 가나에 기술, 전문성을 공유함으로써 전력 } \\
5,000 \text { 메가와트 공급 지원 }\end{array}$ \\
\hline $\begin{array}{c}\text { Symbion } \\
\text { 애후정지원 }\end{array}$ \\
\hline $\begin{array}{c}\text { Aldwych 간 전력 2,000 메가와트 생산 지원을 위한 투자/ } \\
\text { International }\end{array}$ & 18억불 & $\begin{array}{l}\text { 향후 5년간 전력 1,500 메가와트 생산 지원을 위한 투자/ } \\
\text { 재정지원 }\end{array}$ \\
\hline $\begin{array}{c}\text { Harith } \\
\text { General } \\
\text { Partners }\end{array}$ & 5억7천만불 & $\begin{array}{l}\text { 케냐, 탄자니아에 400 메가와트 상당의 풍력에너지 개발 } \\
\text { 지원 및 관련 투자 풍력에너지 개발 지원(7천만불), 아프리카 에너지 } \\
\text { 부문 신규 기금 지원(5억불) }\end{array}$ \\
\hline $\begin{array}{c}\text { Husk Power } \\
\text { Systems }\end{array}$ & - & $\begin{array}{l}\text { 탄자니아에 200개 소규모 발전소 지원, 6만 가구 전등 } \\
\text { (lighting) 공급 지원 }\end{array}$ \\
\hline $\begin{array}{c}\text { The African } \\
\text { Finance } \\
\text { Corporation }\end{array}$ & 12억5천만불 & $\begin{array}{l}\text { 가나, 케냐, 나이지리아 전력 부문 투자(2억5천만불), 사하 } \\
\text { 라이남 아프리카 에너지 프로젝트에 10억불 투자 }\end{array}$ \\
\hline
\end{tabular}

파워 아프리카 1차 대상국은 에티오피아, 가나, 케냐, 라이베리아, 나이지리아, 탄자니아 6 개국이며(석유, 가스 부분 운용에 대해 우간다 및 모잠비크와도 협력), 미국은 이러한 이니셔 3) MCC, Millennium Challenge Corporation : 미국의 독자적 해외원조기관으로 2004년 의회에 의해 설립 
티브의 발표가 $\triangle$ 향후 아프리카 에너지 개발 및 투자를 위한 다양한 주체의 참여 촉진, $\triangle$ 에너 지 분야의 개발과 관리를 위한 역량 강화 및 시장구조의 개선, $\triangle$ 천연자원 운용의 투명성 확보 에 기여할 것으로 기대하고 있다.

\section{2. 무역 아프리카(Trade Africa)}

Power Africa에 이어 발표된 Trade Africa는 사하라 이남 아프리카 국가들의 역내 무역 활 성화와 국제시장으로의 진출 지원을 목적으로 하며, 1단계로 동아프리카공동체(EAC, East African Community) 국가들 - 브룬디, 케냐, 르완다, 탄자니아, 우간다 - 의 대미(對美) 수 출 40\% 증대, 몸바사(Mombasa, Kenya) 및 다레살람(Dar es Salam, Tanzania) 항구에서의 수출입 소요시간 $15 \%$ 감소, 육로 운송 시 국경 통과 소요시간 $30 \%$ 감소를 달성하고자 한다.

1 단계로 $\mathrm{EAC}$ 국가들과의 협력을 강조한 것은 1 억 3 천만이 넘는 시장 규모와 상대적으로 안 정적이고 시장 친화적인 법과 제도에서 기인한다. 또한 $\mathrm{EAC}$ 소속 5 개국의 GDP가 지난 10 년 간 거의 4 배로 증가해 현재 8 백억불을 초과하였으며, $\mathrm{EAC}$ 국가 상호간 무역이 지난 5 년간 2 배로 증대되었다는 사실에 주목한 것으로 보인다.

\section{[EAC 국가의 GDP 성장 추이(2000-2011, 단위:억만불)]4)}

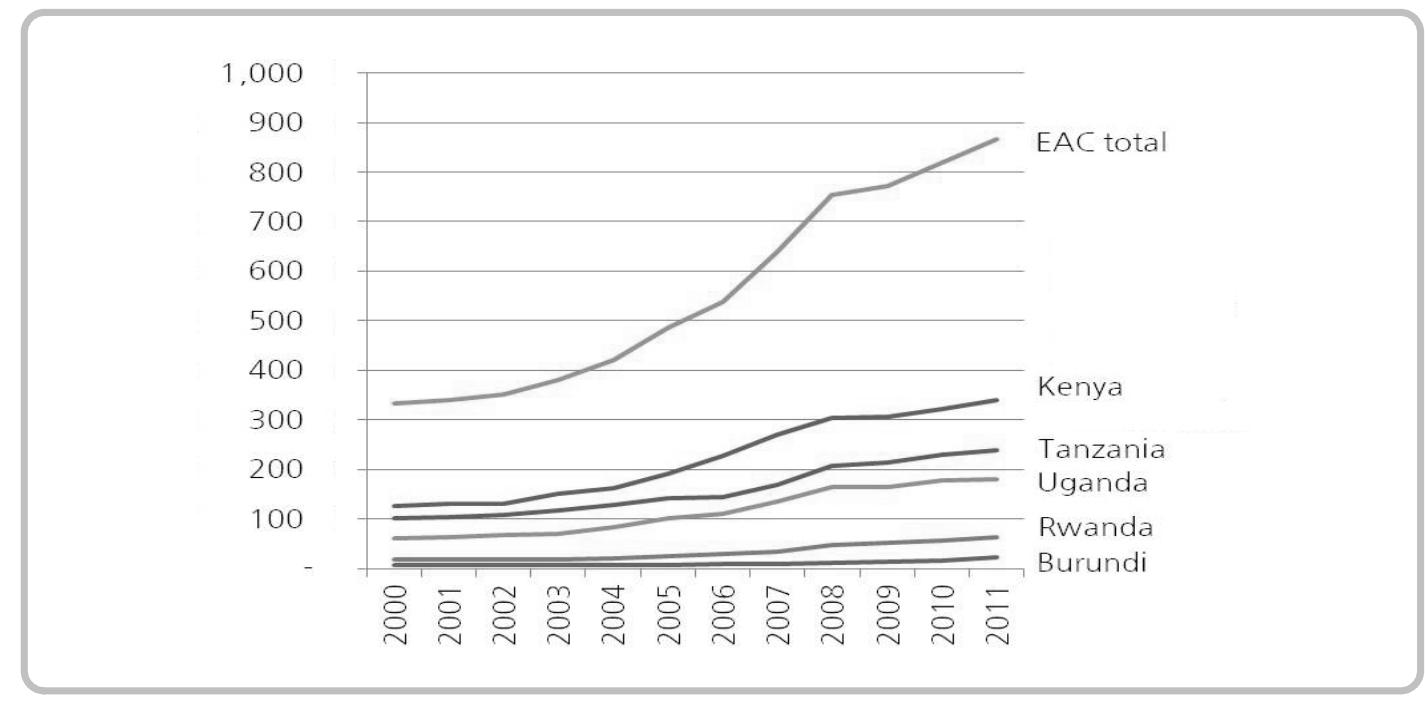

4) East African Community Site : Indicators - GDP at current market prices 
Trade Africa는 크게 $\triangle$ 미국-EAC간 무역/투자 증대, $\triangle \mathrm{EAC}$ 역내 통합 증진, $\triangle \mathrm{EAC}$ 국가 들의 무역경쟁력 강화 지원의 3 가지를 골자로 한다.

\begin{tabular}{c|l}
\hline \multicolumn{1}{c|}{ 구분 } & \multicolumn{1}{c}{ 주요내용 } \\
\hline $\begin{array}{c}\text { 미국과의 무역/ } \\
\text { 투자 증대 }\end{array}$ & $\begin{array}{l}\text { 미국-EAC간 투자협정 검토, 민간부문 참여 확대를 위한 Commercial } \\
\text { Dialogue 구축, 정보제공 및 자문, 위험완화를 위한 무역투자 센터 } \\
\text { 설립, 캠페인 활동 등 }\end{array}$ \\
\hline 역내 통합 증진 & $\begin{array}{l}\text { EAC 단일 세관 (single EAC customs)을 위한 기술 지원, 세관 현대 } \\
\text { 화, 행정 시간소요 절감 }\end{array}$ \\
\hline 무역경쟁력 강화 & $\begin{array}{l}\text { 지속가능한 기업활동을 위한 민간 부문의 역량 강화, 미국-아프리카 } \\
\text { 간 협력관계 공식화, 수출 전략 개발 등 }\end{array}$ \\
\hline
\end{tabular}

\section{3. 사하라 이남 아프리카 식량 안보}

순방기간 중 발표한 파워 아프리카 및 무역 아프리카 외에 식량안보와 농업 분야에 대한 협력 도 재조명되었다. 오바마 정부는 집권 이래 식량안보를 대외정책의 최우선으로 두었다고 강조하 며, 작년 G-8 당시 G-8 국가들과 아프리카 대통령, 아프리카 연합, 민간부문과의 협력을 통해 식량안보와 영양을 위한 신 연대(New Alliance for Food Security and Nutrition)에 착수하고 2022 년까지 사하라 이남 아프리카의 빈곤 인구 5 천만명의 빈곤 탈출 지원을 약속한바 있다.

\section{[오바마 정부의 식량안보 글로벌 리더십 주요내용]}

\begin{tabular}{c|l}
\hline 구분 & \multicolumn{1}{c}{ 주요내용 } \\
\hline 국제사회 동원 & $\begin{array}{l}\text { 2009년 식량안보회의(로마)의 5대 원칙에 따라 국제사회 일원으로 } \\
\text { 식량안보 프로그램 지원, 현재까지 약 220억불 지원 약속함 }\end{array}$ \\
\hline Feed the Future & $\begin{array}{l}\text { 2010년 착수한 미국 정부의 기아와 식량안보를 위한 이니셔티브로, } \\
\text { 협력대상국의 우선순위에 따라 소작농과 여성을 지원함 }\end{array}$ \\
\hline \multirow{3}{*}{ MCC 약속 이행 } & $\begin{array}{l}\text { 아프리카 정부 자체의 식량안보 대응 정책의 수립과 이행에 24억불 } \\
\text { 투자, 주로 아프리카에서 농산물 시장의 가동, 토지이용 권한, } \\
\text { 인프라를 개선할 수 있도록 지원함 }\end{array}$ \\
\hline \multirow{3}{*}{ 다자 협력 } & $\begin{array}{l}\text { 2010년 G-20 국가와 개발도상국, 월드뱅크 및 다자기구와의 } \\
\text { 협력으로 농업 및 식량안보 프로그램을 지원 약속함 } \\
- \text { 미국, 호주, 캐나다, 아일랜드, 일본, 네덜란드, 한국, 스페인, Bill } \\
\text { and Melinda Gates Foundation 등 지원 약속 }\end{array}$ \\
\hline
\end{tabular}


민간부문과의 협력을 통해 작년 한 해 37 억불의 아프리카 농업에 대한 투자가 이루어졌으 며, 협력대상국도 기존 부르키나파소, 코트디부아르, 에티오피아, 가나, 모잠비크, 탄자니아에 서 베넹과 말라위, 나이지리아를 추가했다. 영양의 경우, 면역이 생성되는 시기를 지원함으로 써 빈곤의 고리를 끊는다는 차원에서 여성의 임신부터 아이가 2살이 되는 약 1,000 일간을 우 선적으로 지원했다.

\section{III. 중국 시진핑 주석 아프리카 순방}

중국 시진핑 주석은 3 월 24 일부터 3 월 30 일간 탄자니아와 남아공, 콩고공화국을 순방하며 정상회담과 의회연설, 남아공에서의 우간다, 모잠비크, 에티오피아 정상회담, 제 5 차 BRICS 정상회의 참석을 통해 인프라와 에너지, 무역, 농업, 인적자원 개발을 강조했다.

구체적인 국가별/분야별 지원 약속사항을 확인하기 어려운 관계로, 확인된 일부 약속사항과 함께 중국의 주요 협력분야와 방문기간 중 강조한 사항을 통해 동향을 파악하기로 한다.

\section{1. 지원약속사항}

금번 아프리카 방문기간 중 시진핑 주석은 3년간(2013-2015) 대 아프리카 차관 200억불 및 3 만명 교육/연수, 18,000 명의 중국 연수를 통한 인재 육성을 약속했다. 중국 연수는 중국 각 지의 대학과의 협력을 통해 토목공학 및 산업공학, 환경과학, 약학, 건축, 회계 등 10 개 전공 에 대하여 지원한다.

이의 일환으로 콩고공화국에서는 2013년 정부예산 운용을 위해 11억불 차관 지원을 확정하 였으며, 이에 따라 콩고공화국 정부 예산은 4 조 $\mathrm{Fcfa(현지화),} \mathrm{약} 80$ 억불로 증가할 것으로 보 인다. 


\section{2. 협력분야}

중국은 아프리카의 산업화와 경제성장에 기여한다는 의미로 인프라 확충에 대한 협력을 강 조한다. 도로와 항만, 에너지 등 다양한 하부 분야를 포함하는 인프라 사업은 엄청난 금액의 투자와 긴 상환기간으로 인해 전통적 원조 공여국들이 주저하는 분야이다.

중국은 이미 40년 전 탄자니아-잠비아 연결 철도(TANZARA, Tanzania-Zambia Railroad) 를 건설한바 있으며, 그 과정에서 탄자니아에 입국한 중국인 노동자 5 만명 중 60 명 이상이 사 망한바 있다. 시진핑 주석은 아프리카 도로, 항만, 철도 등 인프라에 투자해온 경험을 토대로 국가간, 지역간 연결이 가능하도록 인프라에 대한 투자 확대 의지를 보였다.

또 강조된 분야는 무역이다. 특히 탄자니아의 경우 중국은 탄자니아의 가장 큰 무역 파트너 이자 두 번째로 큰 투자자로, 2012년 기준 양자교역이 24.7억불에 달하며 이는 전년 대비 $15.2 \%$ 가 상승한 것이다.

탄자니아에서 뿐 아니라 아프리카 전역에서, 특히 자원 부국을 중심으로 중국의 대 아프리 카 차관 및 직접투자, 무역량은 큰 증가세를 보이고 있다. 2009년 중국의 아프리카 교역량은 1,280 억불로 미국의 교역량 1,000 억불을 초과하였으며, 2012년 기준 중국의 투자액만 400 억 불을 초과한다.

\section{[중국의 대 아프리카 수출 추이(단위:억만불)]}

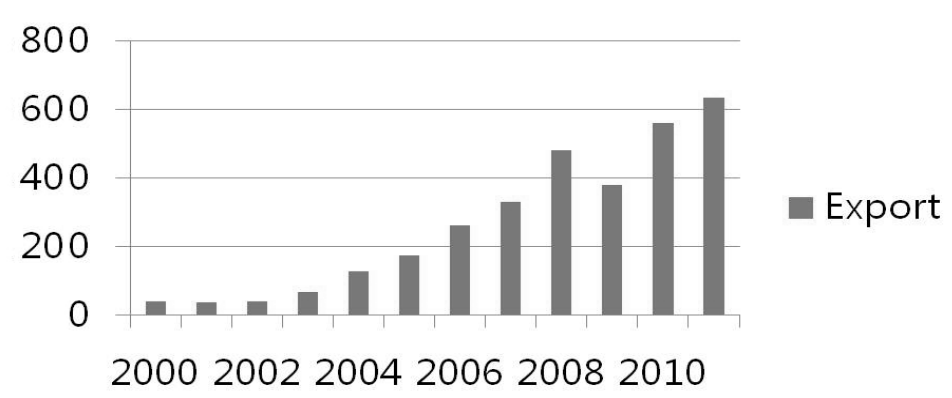

금번 방문에서도 각종 회담 시 무역 증진을 위한 협력을 위해 상호간 합의가 있었으며, 아 울러 기술협력, 농업, 제조 및 인적자원 개발도 중요하게 다루어졌다. 


\section{3. 기타 사항}

중국은 아프리카와의 협력이 남남(南南) 협력임을 강조한다. '개발도상국'의 정의에 논란이 있음에도 불구하고, 중국은 중국이 세계에서 가장 큰 개발도상국이며, 아프리카는 개발도상국 이 가장 많은 대륙임을 강조하며 상호간의 남남협력이 윈-윈이 될 수 있음을 강조한다.

특히, 금번 시진핑 주석의 아프리카 방문기간에 앞서 나이지리아 중앙은행 Lamido Sanusi 총재는, 파이낸셜 타임즈 기고를 통해 중국이 아프리카에서 원자재를 사고 자국의 1 차 공산품 을 판매하는 것은 식민주의 본질적 속성이라고 비판한바 있어, 더욱 금번 방문과 방문에 따른 행보가 양측에 이득을 주는 관계이며 공산품 판매 뿐 아닌 기술이전이 병행된 것임에 초점을 맞춘 것으로 보인다.

아울러, 중국은 아프리카의 뿌리 깊은 우정을 강조한다. 중국은 1991년 이후 매년 외교부장 첫 방문지로 아프리카를 선택하고 있으며, 54 개 아프리카 국가 중 50 개국에 공관을 운영하고 있다. 특히 금번 방문기간 중 남아공에서는 2014년을 남아공의 중국의 해, 중국의 남아공의 해 지정에 합의하기도 했다.

미국을 비롯한 전통적 원조 공여국은 인권과 거버넌스, 젠더, 환경 이슈 등을 강조하며 원 조 수행 시 이러한 요소를 조건으로 거는 경우가 있으나, 중국은 경제협력과 정치적 간섭을 분 리하여 아프리카 국가들의 국내적 정세에 불간섭하는 원칙을 고수하고 있다. 이러한 불간섭에 대해 타 선진국들은 중국이 중요한 가치와 무관하게 거액의 투자금을 아프리카에 유입하는 것 은 사실상의 사보타주(sabotage)와 다름이 없다고 평하기도 한다.

\section{$\mathrm{IV}$. 일본 TICAD 개최 및 아베 이니셔티브}

일본은 6월 1일부터 6월 3일간 보다 역동적인 아프리카와의 협력(Hand in Hand with a More Dynamic Africa)을 주제로 제5차 아프리카 개발을 위한 도쿄 국제 컨퍼런스(TICAD, Tokyo International Conference for African Development)를 개최하고 2013 요코하마 선 언과 행동계획(2013-2017)을 채택하였다. TICAD 기본 세션은 $\triangle$ 탄탄하고 지속가능한 경제, 
$\triangle$ 민간부문 활성화, $\triangle$ 평화와 안정, $\triangle$ 포괄적, 탄력적 사회 4 개로 구성되었으며, 주제별 선택 세션은 $\triangle$ 민간부문, 무역과 투자, $\triangle$ 성장을 위한 부문별 기초 강화, $\triangle$ Post- $2015, \triangle$ 양성 평 등과 여성역량 강화, $\triangle$ 평화 구축으로 이루어졌다. (이하 요코하마 행동계획 주요내용 요약)

\section{1. 무역과 투자, 민간주도적 경제성장}

오늘날 아프리카는 전 세계에서 가장 덜 통합된(least integrated) 지역으로, 전 세계 무역 에서 아프리카의 무역이 차지하는 비중은 $3 \%$, 전체 무역 대비 역내 무역이 차지하는 비중은 $12 \%$ 에 불과하다. 무역은 새로운 시장을 형성하고 고용을 창출하며, 원가의 절감, 생산성과 경 쟁력 향상, 나아가 빈곤 감소에 기여한다는 측면에서 아프리카의 경제발전을 위한 필수 요소 라 할 수 있다.

[대륙별 무역 비중(2011)]5)

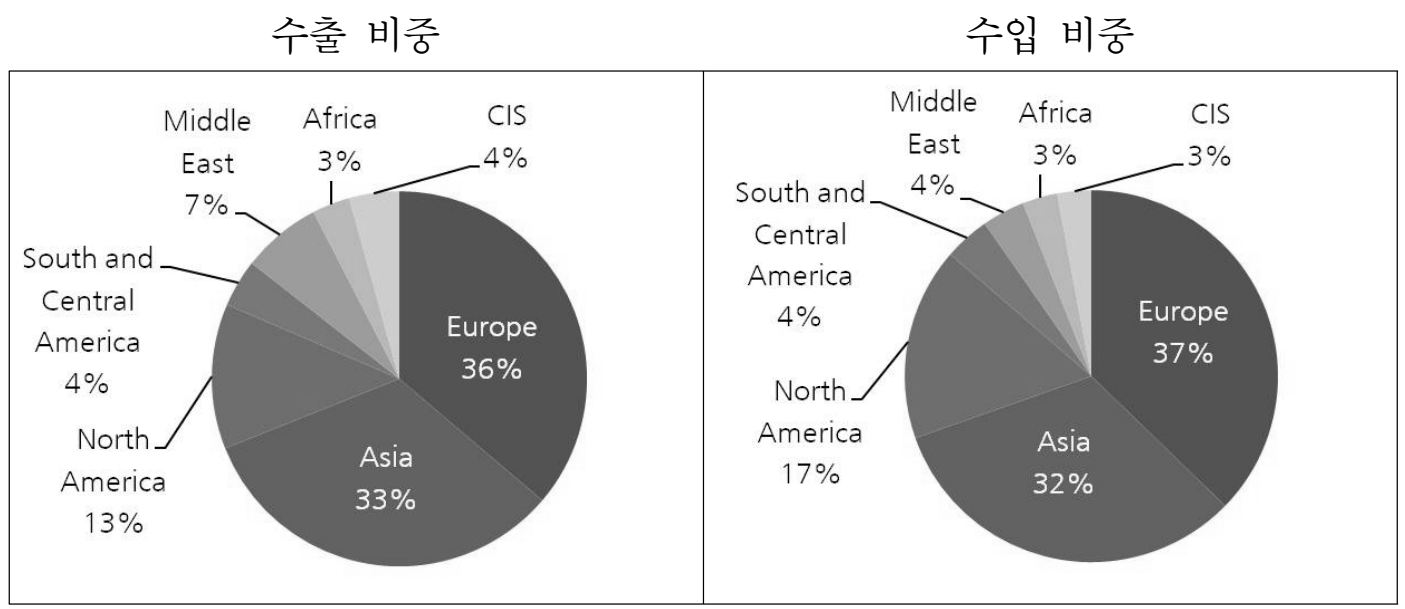

아프리카에서 민간 자본의 유입량은 이미 공적개발원조(ODA) 금액을 초과하였으며, 중산층 의 확대에 따라 다양한 시장이 형성되었다. ICT, 모바일 산업 등 아프리카에서 몇 가지 시장 의 성장은 특히 주목할 만하다. 이러한 민간부문의 확대는 고용을 창출하고 가계 소득을 증대 하는데 기여할 것으로 기대되며, 원조에 대한 의존도를 낮추고 궁극적으로 지속가능한 개발을 달성하는 데 도움이 될 것으로 보인다.

5) WTO International Trade Statistics 2012, Historical Trends 
다만 아프리카 대부분의 국가들은 무역과 투자를 유치하기에 국제 시장에서 초보 단계이며, 따라서 민간에 매력적인 시장으로 발돋움하기 위해서는 법과 제도의 정비, 인프라 보강, 계획 수립 등 정부 차원의 움직임이 필요하다. 마찬가지로, 상대국 역시 공기업의 진출, 정부차원의 민간 진출 지원 등 방법을 검토해야 할 것이다.

\section{2. 인프라 확충 및 인적역량 강화}

아프리카 자체적으로 지속가능한(self-sustaining) 성장을 도모하기 위해 TICAD에서는 기 초인프라 확충과 인적역량 강화를 2 가지 주요 요소로 강조하며, 더불어 과학 기술의 발전도 역량 강화의 일환으로 언급하였다.

부족한 인프라는 기업 활동을 저해하는 가장 큰 요소로, 생산비용과 거래비용을 높임으로써 기업의 경쟁력을 감소시킨다. 교통 인프라의 부족은 주요 수요와 공급처간 연결을 어렵게 하 며, 아프리카 전체가 직면하고 있는 전력 문제는 민간의 활동을 위축시키고 경제성장을 저해 한다. 교통과 에너지 인프라 확충을 위한 아프리카 인프라 개발 프로그램(PIDA, Programme for Infrastructure Development in Africa)6)에 따르면, 2012-2020년간 우선행동계획 (PAP, Priority Action Plan) 이행을 위해 총 680억불이 필요하며, 2040년까지의 장기 개발 을 위해서는 3,600 억불 이상이 필요하다. 이에 대한 지원과 투자, 협력이 필요한 시점이다.

일본은 성장을 위한 또 하나의 요소로 초등교육 이후의 교육 - 고등교육 및 직업교육 - 의 중요성을 강조한다. 이러한 교육의 커리큘럼이 실제 노동시장의 수요에 부합하도록 구성되어 우수한 인력이 시장으로 배출되는 것이 경제 성장을 위한 주요 요인으로 보는 것이다. 아울러, 중앙정부와 지방정부 레벨의 공무원 역량강화를 통해 정부가 경제성장을 위한 효율성을 제고 하도록 하고, 법과 제도를 정비함으로써 거버넌스를 확립하는 것 또한 강조하고 있다.

6) PIDA에 포함된 분야는 1) 에너지 - 전기(원자력 포함), 천연가스, 석유 및 기타 재생에너지, 2) 교통 - 항공, 도로, 철도, 선박 등, 3) ICT - 통신 및 ICT 망 구축, 4) 수자원 - 관개, 수력발전, 호수와 강에서의 교통으로 구분됨. PIDA, General Terms of Reference, African Union 


\section{3. 경제활동 주체로서의 농업인력 양성}

농업은 아프리카 경제에서 가장 큰 비중을 차지하는 분야로, 포괄적 아프리카 농업개발 프 로그램(CAADP, Comprehensive African Agriculture Development Program) 채택 및 추진 이후 농업분야의 진전이 이루어졌으나 다양한 세부 분야의 개선을 위한 지속적인 노력이 필요 하다. TICAD에서는 농업분야 발전을 위해 정부는 공공재의 보급과 농업경제 활성화를 위한 환경 조성을 위해 노력하고 민간부문은 생산성 향상과 농산품 가공을 통해 경제 성장에 기여 할 것을 강조한바 있다.

아울러 농업분야의 발전을 위해 대규모 경작 뿐 아니라 여성을 포함한 소작농의 생산력 증 진, 자연재해로 부터의 대응, 농업분야 연구개발의 중요성을 언급하고 이러한 농업 분야의 발 전이 아프리카의 경제 성장으로 이어짐과 동시에 식량안보와 기아근절에 기여할 것으로 기대 했다.

\section{4. 지속적, 탄력적 성장}

아프리카 경제는 지난 몇 년간 지속가능한 성장을 위해 다양한 측면에서의 진전을 이뤄왔으 나 아직까지 자연재해와 기후변화 대응의 측면에서 볼 때 가장 취약한 지역으로 볼 수 있다. 기후변화는 농/어업을 통해 경제활동을 하는 아프리카 국가에 심각한 영향을 미칠 수 있으며, 생물 다양성 보존과 사막화 방지를 위해서도 중요한 이슈가 아닐 수 없다.

다양한 종류의 자연재해 중 아프리카에서 가장 심각한 것은 가뭄이며, 태풍이나 홍수가 주 로 토지나 재산에 영향을 미치는 반면 가뭄은 많은 사람들의 생명을 앗아간다. 이러한 자연재 해는 기후변화와 밀접한 관계가 있으며, TICAD는 아프리카의 지속적, 탄력적 성장을 위한 기 반으로 기후변화와 자연재해 문제를 거론하고 있다.

\section{5. 성장을 위한 포괄적 사회 구축}

천년개발목표의 달성을 위해 교육과 보건의료, 물과 위생에 대한 노력을 가속화할 필요가 
있다. TICAD에서는 빈곤을 줄이고 인간기본욕구 충족을 위한 프로그램을 계속할 것을 강조했 다. 교육 분야의 경우, 아프리카에서 모두를 위한 교육 이니셔티브(Education for All Initiative)를 통해 초등교육 접근성 향상을 이룬바 있으며, 모성사망률 및 영아사망률도 1990 년대에 비해 감소한 것으로 나타났다.

그러나 여전히 아프리카 대다수의 국가들이 천년개발목표의 보건의료 지표를 달성하기 어 려운 상태이며, 특히 모자보건과 생식보건 증진, 보편적 보건 시스템 구축, 안전한 식수 이용 증대와 안전한 폐기물 처리 등의 노력이 필요하다. 이러한 노력은 인간의 존엄성 확보 및 인간 안보 증진과 직결되며, 향후 아프리카가 자립적인 성장을 하기 위한 동력이 된다.

\section{6. 평화와 안정, 민주주의, 거버넌스}

평화와 안정은 경제사회 발전의 근간이 된다. 아프리카는 지난 20 여년에 걸쳐 평화와 안정 에 있어 큰 진전을 이루었으며, 이러한 발전의 과정에서 아프리카연합과 지역 경제공동체의 역할이 컸다. 그러나 사헬지역과 소말리아 인근, 콩고 동부 국경지대를 중심으로 분쟁이 지속 되고 있으며, 분쟁의 예방과 관리, 평화 구축을 위한 지속적인 노력이 필요하다.

$\mathrm{TICAD}$ 에서 민주주의와 거버넌스 역시 경제사회 발전을 위한 근간으로 언급한바 있으며, 정 부의 역량과 효율성 강화, 부패방지를 위한 지원을 강조했다.

일본은 금년 제 5 차 $\mathrm{TICAD}$ 에서 위의 6 가지 이슈를 현 시점 대 아프리카 개발 과제로 중점 다루는 동시에, 경제 성장이 이루어지기 위해서는 민간의 참여가 중요하다는 것을 재차 강조 하고, 아프리카에서 활동중인 일본 민간기업을 중심으로 특별 세션을 마련하여 아프리카에서 의 성과와 위험요소를 공유하도록 하기도 했다.

아울러, 일본은 TICAD 20주년 및 아프리카연합 50 주년을 기념하며 금번 회의 계기에 아프 리카 경제성장 및 인간안보 증진을 위한 아프리카 지원 패키지(Japan's Assistance Package for Africa at TICAD V)를 발표하고, ODA 140 억불을 포함한 총 320 억불의 대 아프리카 지원 및 민간 투자를 공약했다. 특히, 아프리카 청년을 위한 아베 이니셔티브(ABE Initiative, African Business Education Initiative for Youth)를 발표하며 아프리카 청년 1,000명을 일 본으로 초청, 역량강화 프로그램을 지원할 것을 약속하기도 했다. 
[일본의 대 아프리카 지원 패키지 주요내용]

\begin{tabular}{|c|c|}
\hline 지원전략 & 주요내용 \\
\hline $\begin{array}{l}\text { 민간 주도적 경제 } \\
\text { 성장 }\end{array}$ & $\begin{array}{l}\text { 일본무역보험(NEXI, Nippon Export and Investment Insurance)을 } \\
\text { 통한 최대 } 20 \text { 억불 지원, 아프리카 } 10 \text { 개국 투자 진흥을 위한 } \\
\text { 정책자문관 파견, 아프리카개발은행과의 co-financing(5억불)을 } \\
\text { 통한 민간 부문 성장 지원 }\end{array}$ \\
\hline $\begin{array}{l}\text { 인프라 확충 및 } \\
\text { 역량강화 }\end{array}$ & $\begin{array}{l}\text { 인프라 부문 } 65 \text { 억불 유무상 재정 지원, 아베 이니셔티브 (African } \\
\text { Business Education Initiative for Youth)를 통한 아프리카 청년 } \\
1,000 \text { 명 일본 초청 }\end{array}$ \\
\hline $\begin{array}{l}\text { 경제주체로서 } \\
\text { 농업인 역량 강화 }\end{array}$ & $\begin{array}{l}\text { 2018년까지 사하라이남 아프리카의 쌀 생산량 2배 증대 지원, } \\
\text { 생계형 농민에서 상업형 농민으로의 전환 프로그램 추진, } \\
1,000 \text { 명의 농업지도자 육성 }\end{array}$ \\
\hline $\begin{array}{l}\text { 지속적, 탄력적 } \\
\text { 성장 }\end{array}$ & $\begin{array}{l}\text { 34개국의 사막화 방지 지원, 저탄소 에너지를 위한 } 20 \text { 억불 } \\
\text { 재정지원, 도서국가 대상 재난위험 감소 지원 }\end{array}$ \\
\hline 포괄적 사회 구츨 & $\begin{array}{l}\text { 2천만 아동 대상 교육기회 제공, } 12 \text { 만명의 보건 증진을 위한 } 5 \text { 억불 } \\
\text { 재정지원, 천만명 대상 식수/위생 접근권 강화 }\end{array}$ \\
\hline $\begin{array}{l}\text { 평화, 안보, } \\
\text { 거버넌스의 구축 }\end{array}$ & $\begin{array}{l}\text { 사헬지역 안정을 위한 } 10 \text { 억불 상당 개발 및 인도적 지원, } \\
\text { 사법부·언론·지방정부 소속 5천명 거버넌스 역량강화, PKO 지속 } \\
\text { 파견 }\end{array}$ \\
\hline
\end{tabular}

\section{V. 시사점}

미국과 중국 정상의 아프리카 방문과 일본 TICAD를 통해 살펴본 미국, 중국, 일본의 대 아 프리카 협력 동향은 협력 규모의 확대와 특성화, 민간 참여 확대 (다양한 파트너의 모색), 전 통적 분야의 지속지원에 대해 시사하는 바가 크다.

\section{1. 대 아프리카 협력규모 확대 및 특성화}

우리의 경제규모에 비추어 대 아프리카 협력규모를 상기 3국과 비교할 수 없겠으나 협력규 모의 확대는 매우 중요하다. 아프리카의 많은 국가들이 국가 자원 운용에 대한 역량이 부족하 
고 거버넌스가 취약하며, 일부 법과 제도가 갖추어져 있다 하더라도 우리와 체계가 다른 경우 가 많기 때문에, 실제로 아프리카에서는 “누구를 아는지가 가장 중요하다”고 말한다. 많은 부 분 시스템에 의존하기 보다는 의지를 가진 사람의 역량에 기대해야 하기 때문이다.

현재 우리의 협력규모는 아프리카 국가들의 입장에서 괄목할만한 정도가 아니며, 자연스럽 게 민간 교류가 활성화되기 전까지는 더욱 정부의 협력과 투자가 필수적이라 하겠다.

아울러, 규모 확대와 동시에 한국의 독자적인 개발경험을 공유하는 등 특성화에도 주력해야 할 것이다. 반세기만에 최빈국에서 세계 10 대 규모의 경제 강국으로 성장한 경험은 아프리카 국가들과의 교류 활성화에 주춧돌이 될 것이다.

다만, 개발경험 공유라는 명목 하에 실제 우리에게 모든 경험이 있었던 것으로 오해하는 것 은 경계해야 할 것이다. 다민족간의 갈등, 넓은 국토의 개발, 자연자원의 활용, 내륙국의 무역 과 교통 등은 우리가 경험하지 못한 것이나 아프리카 많은 국가들의 개발에서는 필수적으로 고려되어야 할 요소이다. 이를 보완하기 위해서는 특성화와 함께 여타 공여국과의 삼각협력이 나 다자기구와의 협력도 고려할 수 있을 것이다.

\section{2. 민간 참여의 확대}

미국은 원조가 아닌 무역을 강조하며 아프리카 순방시 정부 차원의 약속과 더불어 민간 투 자를 약속하였으며, 중국 기업의 아프리카 진출은 이미 잘 알려져 있다. 일본 역시 TICAD에 서 민간 주도적 경제성장을 강조하며 미츠비시 등 아프리카에 진출한 일본 기업과의 간담회를 주도하기도 했다.

일방적인 원조는 기술이전이나 투자로 이어지지 않으며 따라서 지속가능성을 확보하는 것 에 어려움이 있다. 또한, 거대한 땅인 아프리카에서 필요로 하는 많은 프로젝트는 정부차원의 원조규모만으로는 감당하기 어렵다. 따라서 정부의 지원이 민간의 아프리카 진출과 연계되어 기술이전과 고용창출, 무역 확대가 이루어질 수 있는 방향으로 이루어져야 할 것이다.

정부 통신망 구축사업, 행정 역량 강화사업, 관세행정 현대화 사업 등 주로 민간이 일할 수 있는 환경을 조성하는 기반을 구축하는데 기여할 수 있는 사업과 더불어, 직접적으로 유상원 
조나 기업 진출로 이어질 수 있는 타당성 조사, 실시설계 사업 등이 민간 참여를 도모하는데 기여할 수 있을 것으로 보인다.

\section{3. 전통적 원조 분야에 대한 지원 지속}

우리나라가 아프리카에 대해 심리적 거리감을 갖고 있는 것은 지리적으로 먼 것이 큰 이유 이겠으나, 내전과 기아, 질병으로 대변되는 아프리카의 이미지 때문이기도 하다. 역으로 생각 하면, 지난 10 여년에 걸쳐 국내에서 아프리카에 대한 인식은 크게 변화되었으며, 이는 실제로 아프리카에 평화가 정착되고 질병이 감소하는 등 전통적 원조 분야에 대한 지원이 성과를 거 둔 것이 현재 다양한 참여자의 진출을 도모할 수 있는 환경적 기반을 만들었다고 볼 수 있다.

보건의료 분야에 있어서 모성 사망률과 영유아 사망률이 감소하였으며, 교육 접근권이 강 화되었다. 많은 아프리카 국가들이 투명성의 의혹이 있을지언정 선거를 통해 국민의 대표를 선출하며, 평화와 안보, 거버넌스 측면에서 상당한 진전이 있었다.

민간 투자와 인프라, 에너지에 대한 관심이 높아지고 기업 진출을 도모하는 것에 대하여 개 발의 측면에서 주목하되, 여전히 전통 분야에 대하여, 특히 2015년까지 달성하기 어려울 것으 로 보이는 천년개발목표의 지표들에 대하여 지원을 지속해야 할 것이다. 이러한 기반이 후퇴 할 경우, 현 시점에서 논의되는 민간의 진출과 투자, 무역 모두 함께 후퇴할 수밖에 없을 것이다.

\section{VI. 결어}

우리는 그동안 아프리카 이니셔티브, 정부 차원의 무유상 중점협력국 선정. OECD 개발원조 위원회 가입 등 몇 번의 계기에 아프리카, 특히 최빈국과의 협력을 강화하고 지원을 확대하는 계기를 마련한바 있다. 지원 규모를 확대하고 아프리카에 대한 정책을 수립-이행하는 것은 단기간에 이루어질 수 있는 것이 아니며 지속적인 의지와 노력이 병행되어야 할 것이다.

아프리카는 기존 외교관계를 주력해오던 나라와 달리 관계의 역사가 짧으며 제도적으로, 문 
화적으로 상호간 적응의 시기가 필요하다는 것도 인정해야 할 사실이다. 아프리카에는 체계가 없어 우리가 구축해주면 되는 것이 아니고, 정보의 부족으로 체계가 수면에 보이지 않거나 과 거 식민종주국의 영향으로 체계가 우리와 다를 뿐이다. 따라서 원조를 통해 무에서 유를 창조 해주겠다는 사고는 지양해야 할 것이며, 우리 관점에서의 사고에서 빨리 벗어날수록 위험요인 을 줄이게 될 것이다.

아울러, 한정된 자원으로 한국이란 나라가 아프리카에 알리고자 하는 메시지가 무엇이며, 어떻게 이 메시지를 개발협력 정책에 반영할 수 있을지도 고민해야 할 것이다. 미국은 평화와 거버넌스를 적극 지원하며 반군 지원이 의심되는 경우 원조 금액을 삭감하기도 한다. 에너지 와 경제협력도 강조되고 있으나, 여전히 민주주의 정착은 중요한 키워드인 셈이다. 반면 중국 의 여타 공여국의 질책에도 상대국의 국내적 정세는 묵인하며 윈-윈을 강조하고 인프라와 자 원에 주력하는 모습이다.

수원국에서 공여국으로 발전한 독특한 경험이 있으며 이를 통해 개발경험을 공유함으로써 아프리카 최빈국의 멘토 역할을 하는 것이 우리의 키워드라면, 구체적으로 공유할 수 있는 경 험과 우리에게 없는 경험을 구분하고, 무엇을 공유함으로써 어떤 메시지를 던지고자 하는지를 구체화하는 작업 또한 필요할 것이다.

본 글이 간략하게나마 우리나라와 밀접한 관계가 있는 3 국의 대 아프리카 지원규모와 분야 등 동향을 소개함으로써 우리나라의 대 아프리카 협력의 현주소를 점검하고 앞으로의 방향을 정립하는데 기여하길 기대한다. 


\section{참고문헌}

백악관 보도자료, Fact Sheet-Power Africa 백악관 보도자료, Fact Sheet-Trade Africa

백악관 보도자료, Fact Sheet-Food Security in Sub-Saharan Africa

Yale Global Magazine, China and the US Court Africa

Brookings Institution, China's Interest in Africa (2013.4, Yun Sun)

Brookings Institution, China in Africa: Implications for US Competition and Diplomacy (2013.4, Yun Sun)

http://www. xinhuanet.com/english/special/xjp20130322/

- 시진핑 주석 아프리카 순방 주요 자료

TICAD Yokohama Declaration, Yokohama Action Plan (2013-2017)

TICAD Concept note for Plenary Sessions / Themaric Sessions 1-5

http://www.mofa.go.jp/region/page2e_000002.html

- 일본 외무성 TICAD 홈페이지 자료

Programme for Infrastructure Development in Africa (PIDA) Action Plan

East African Community Site : Indicators

WTO International Trade Statistics 2012, Historical Trends 